Article

\title{
Immobilization of Enterobacter aerogenes by a Trimeric Autotransporter Adhesin, AtaA, and Its Application to Biohydrogen Production
}

\author{
Hajime Nakatani ${ }^{\dagger}$, Nan Ding ${ }^{\dagger}$, Yuki Ohara and Katsutoshi Hori * \\ Department of Biomolecular Engineering, Graduate School of Engineering, Nagoya University, Furo-cho, \\ Chikusa-ku, Nagoya 464-8603, Japan; nakatanih@chembio.nagoya-u.ac.jp (H.N.); dingnaner@aliyun.com (N.D.); \\ ohara.yuuki@g.mbox.nagoya-u.ac.jp (Y.O.) \\ * Correspondence: khori@chembio.nagoya-u.ac.jp; Tel.: +81-52-789-3339 \\ + These authors contributed equally to this work.
}

Received: 30 March 2018; Accepted: 13 April 2018; Published: 16 April 2018

\begin{abstract}
Biological hydrogen production by microbial cells has been extensively researched as an energy-efficient and environmentally-friendly process. In this study, we propose a fast, easy method for immobilizing Enterobacter aerogenes by expressing ata $A$, which encodes the adhesive protein of Acinetobacter sp. Tol 5. AtaA protein on the E. aerogenes cells carrying the ata $A$ gene was demonstrated by immunoblotting and flow cytometry. The AtaA-producing cells exhibited stronger adherence and auto-agglutination characteristics than wild-type cells, and were successfully immobilized (at approximately $2.5 \mathrm{mg} / \mathrm{cm}^{3}$ ) on polyurethane foam. Hydrogen production from the cell-immobilized polyurethane foams was monitored in repetitive batch reactions and flow reactor studies. The total hydrogen production in triple-repetitive batch reactions reached $0.6 \mathrm{~mol} / \mathrm{mol}$ glucose, and the hydrogen production rate in the flow reactor was $42 \mathrm{~mL} \cdot \mathrm{h}^{-1} \cdot \mathrm{L}^{-1}$. The AtaA production achieved simple and immediate immobilization of E. aerogenes on the foam, enabling repetitive and continuous hydrogen production. This report newly demonstrates the production of AtaA on the cell surfaces of bacterial genera other than Acinetobacter, and can simplify and accelerate the immobilization of whole-cell catalysts.
\end{abstract}

Keywords: hydrogen production; Enterobacter; immobilization; trimeric autotransporter adhesin; cell surface engineering; whole-cell catalyst; surface display

\section{Introduction}

Biological hydrogen production promises a less energy intensive and more environmentally friendly process than traditional processes [1,2]. Most bioprocesses occur at ambient temperatures and pressures. More importantly, they generate hydrogen from various waste biomasses, such as industrial and agricultural organic wastes and wastewaters [2-6]. Hydrogen conversion bioprocesses by heterotrophic bacteria can be classified into two types: light-dependent and light-independent. Light-dependent processes include biophotolysis by cyanobacteria and photo-fermentation by photosynthetic bacteria, which need light energy for hydrogen production [7]. These bioprocesses are disadvantaged by the requirement for lighting throughout the process and the low efficiency of the light-energy conversion. Light-independent hydrogen-production processes include microbial electrolysis [8] and dark fermentation under anaerobic conditions [9]. Dark-fermentation is the most promising of these two approaches, and has been well studied. Although several bacterial species reportedly produce hydrogen via dark-fermentation in pure culture [9], the facultative anaerobes belonging to genus Enterobacter are often exploited for this purpose, because they are easily grown and completely consume the residuary oxygen in the reactor before starting the hydrogen 
production [10]. Mutant strains of E. aerogenes isolated in previous research have demonstrated high hydrogen productivity via fermentation on several substrates [5,10-12].

In most exploratory studies, bio-hydrogen production under dark fermentative conditions has been implemented by the batch-reactor method, which is simply operated and efficiently controlled. However, the development of continuous production processes is recommended for large-scale industrial operations, which must be practically and economically viable [13]. To achieve effective continuous hydrogen production, many studies have developed the cell immobilization method. Cells affixed by various immobilization strategies have been evaluated for their performance as biohydrogen producers [4,14-19]. Unlike planktonic cells, immobilized cells can be repeatedly used in continuous hydrogen production, because the stability and durability of them during the process is enhanced by the immobilization. However, conventional immobilization methods are hindered by complex processes or long startup periods, which increase the manufacturing costs of the immobilized whole-cell catalysts.

Previously, we discovered a bacterial nanofiber protein, Acinetobacter trimeric autotransporter adhesin (AtaA), which plays a vital role in cell adhesion and auto-agglutination of its natural producer, Acinetobacter sp. Tol 5 [20-25]. AtaA belongs to the protein family of trimeric autotransporter adhesins (TAAs), which participate in cell adhesion of Gram-negative pathogens to biotic materials in their host tissues [26,27]. Unlike other TAAs, AtaA mediates adhesion to various abiotic materials such as plastics, glass, and stainless steel $[20,24]$. Importantly, introducing the ata $A$ gene induces these features in non-adhesive and non-agglutinating Acinetobacter species. We developed a new immobilization method for bacterial cells on the basis of a kind of physical adsorption mechanism through AtaA [28,29]. However, the immobilization of bacterial species other than Acinetobacter has not been reported. In this study, we demonstrate the first evidence that E. aerogenes beyond the Acinetobacter genus can be immobilized by expressing ataA, and that the immobilized cells can be utilized in repetitive and continuous hydrogen production. We chose polyurethane foam as a typical carrier material for microbial cells. It is light, durable, inexpensive, and easy to handle material, and is practically used for wastewater treatment [30-32].

\section{Results}

\subsection{Production of AtaA on the Cell Surface of E. aerogenes}

The E. aerogenes cells were transformed by conjugal transfer from Escherichia coli harboring pAtaA, and the transformant was analyzed for AtaA production by sodium dodecyl sulfate-polyacrylamide gel electrophoresis (SDS-PAGE) followed by immunoblotting (Figure 1A). The AtaA protein band $(\sim 300 \mathrm{kDa})$ was detected in the outer membrane fraction prepared from the transformant by immunoblotting with anti-AtaA antibody (Figure 1A). This result confirmed AtaA production by the transformant cells. Surface display of AtaA on the cell was then confirmed by immunocytostaining of the transformant cells. In the flow cytometry analysis, the fluorescent signal for AtaA on the cell surface of the transformant was clearly more positive than that of wild-type cells (Figure 1B). These data demonstrate the surface display of AtaA on E. aerogenes.

\subsection{AtaA-Mediated Immobilization of E. aerogenes}

The cell adhesion, auto-agglutination, and immobilization of the transformant were analyzed. Crystal Violet staining of the adherent cells on polystyrene (PS) plates revealed a clearly greater adhesion of the E. aerogenes transformant than the wild-type (photographs in Figure 2A, inset). Quantitatively, the cell adhesion was 19 times higher in the transformant than the wild-type cells (Figure 2A). Auto-agglutination of the transformant cells was then observed by tube-settling assay. The transformant sank faster than the wild-type cells, and approximately $40-50 \%$ of the transformant cells were sedimented in $3 \mathrm{~h}$ (Figure 2B). These data demonstrate that E. aerogenes acquired adhesive and auto-agglutinative properties by expressing ataA. 
A

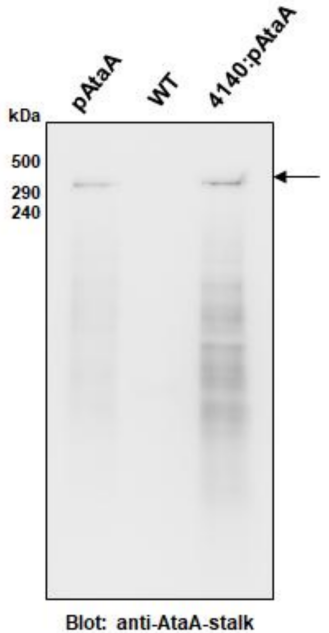

B

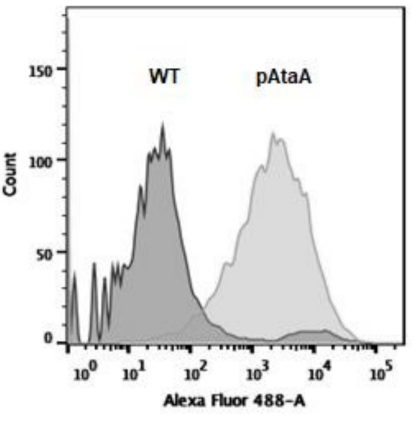

Figure 1. Expression and production of AtaA in Enterobacter aerogenes IAM1183. (A) Immunoblotting of outer membrane proteins prepared from the wild-type E. aerogenes IAM1183 (middle lane) and the cells transformed with the pAtaA construct (left lane) or Tol 5 4140::pAtaA (positive control, right lane). Arrow points to the detected band of the full-length AtaA protein. (B) Flow cytometry analysis for confirming surface display of AtaA on the transformant.

A

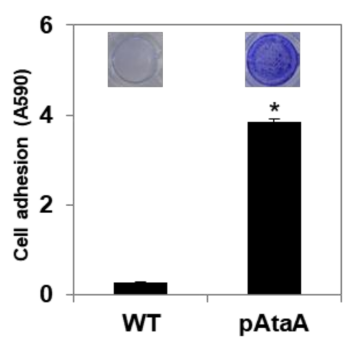

B

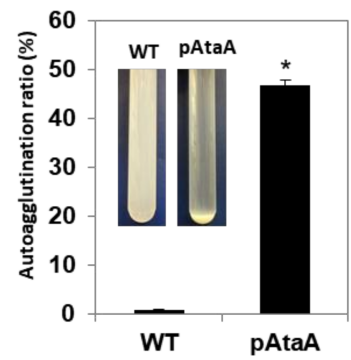

Figure 2. Adherence and auto-agglutination assay of Enterobacter aerogenes-expressing ataA. (A) A cell suspension was placed on the polystyrene plate, and the cells adhering to the bottom of a 48-well were stained with Crystal Violet (photographs, inset). Adherent cells were quantified by measuring the Crystal Violet absorbance at $590 \mathrm{~nm}$. (B) The sediment of the transformant at the bottom of the test tube was observed after settling for $3 \mathrm{~h}$ (photographs, inset), and the auto-agglutination ratio was calculated from the $\mathrm{OD}_{600}$ decrease in the upper segment of the cell suspension. Data are the mean $\pm \mathrm{SD}$ of three independent measurements. Significant differences between the data (student $t$-test, $p<0.01$ ) are marked with asterisk $\left(^{*}\right)$.

We next attempted instant and direct immobilization of ataA-expressing E. aerogenes on polyurethane foams, as previously demonstrated by ataA-expressing Acinetobacter [28]. We first optimized conditions for AtaA-mediated immobilization of E. aerogenes cells onto the polyurethane foam, and found the suitable conditions; the cells were suspended in BS-N medium to 4.0 of $\mathrm{OD}_{600}$, shaken in the presence of polyurethane foams at $115 \mathrm{rpm}$ at $30^{\circ} \mathrm{C}$ for $2 \mathrm{~h}$. After merely shaking the polyurethane foams and a cell suspension of the transformant cells in a flask for $2 \mathrm{~h}$, the turbidity was decreased (Figure 3A), and the immobilized cell density on polyurethane foams was approximately 5 times higher than that of the planktonic cells (Figure 3B). The immobilized cell concentration in the polyurethane foams reached $2.5 \mathrm{~g}$-dry cell weight (DCW)/L-medium. The loading capacity of the polyurethane foams was calculated to be $80 \mathrm{mg}$-DCW/g-foam. In contrast, the wild-type cells were not immobilized by shaking with polyurethane foams in a flask; after $2 \mathrm{~h}$, the cell density on polyurethane foams was lower than that of the cells that remained in the planktonic state (Figure 3B). 
The result clearly showed that ataA expression enhances the immobilization of E. aerogenes on the polyurethane foam.

A

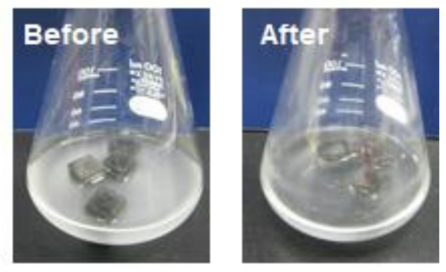

$\mathrm{B}$

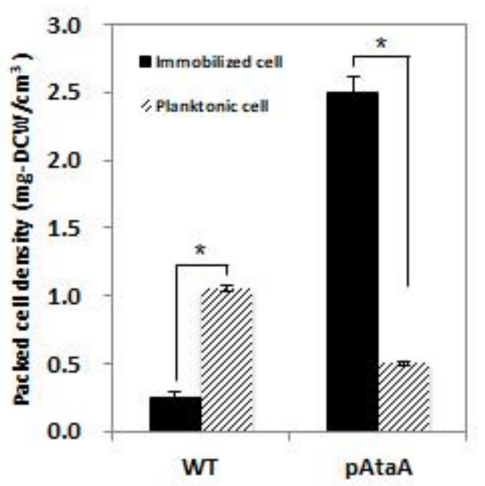

Figure 3. Immobilization of ataA-expressing E. aerogenes on polyurethane foams. A cell suspension of the transformant was shaken with polyurethane foams in the flask. (A) A clear suspension was observed after $2 \mathrm{~h}$ of shaking. (B) Immobilized cells were detached from the 4 pieces of polyurethane foams, and the cells were freeze-dried for dry cell weight (DCW) measurements. The DCW of the remaining cells in the $20 \mathrm{~mL}$ of suspension was also measured. Dry cell densities packed in the unit volume were calculated. Data are the mean \pm SD of three independent studies. Significant differences between the data (student $t$-test, $p<0.01$ ) are marked with an asterisk $\left(^{*}\right)$.

\subsection{Repetitive and Continuous Hydrogen Production by Immobilized E. aerogenes}

Figure $4 \mathrm{~A}$ describes batch-mode repetitive hydrogen production utilizing immobilized E. aerogenes on polyurethane foams. The processes was performed under the restriction of a nitrogen source $\left(0.02 \mathrm{~g} / \mathrm{L}\left(\mathrm{NH}_{4}\right)_{2} \mathrm{SO}_{4}\right)$ to prevent cell growth during the reaction. The glucose consumption and hydrogen production in the batch reactor were measured during each reaction (Figure 4B).

When most of the glucose was consumed, the cell-immobilized polyurethane foams were transferred to new reaction medium for the next hydrogen production. At least three batch reactions were completed by the cell-immobilized polyurethane foams, whereas the polyurethane foams shaken with wild-type cells were unavailable for repetitive hydrogen production because an insufficient quantity of the cells was immobilized on the carrier (Figures $3 \mathrm{~B}$ and $4 \mathrm{~B}$ ). Batches 1, 2, and 3 of the transformant-adhered foams yielded approximately $0.4,0.6$, and $0.4 \mathrm{~mol} / \mathrm{mol}$ glucose of hydrogen, respectively.

Finally, we constructed a flow reactor for hydrogen production (Figure 5A) and measured the hydrogen production during continuous culture. The transformants immobilized on the polyurethane foams or cultured under planktonic conditions (without polyurethane foams) were loaded into the reactor. These processes were also performed under the restriction of a nitrogen source. Hydrogen production by the immobilized cells continued for at least $30 \mathrm{~h}$, and the hydrogen production rate from 5 to $30 \mathrm{~h}$ was $42 \mathrm{~mL} \cdot \mathrm{h}^{-1} \cdot \mathrm{L}^{-1}$. In contrast, hydrogen was hardly produced in the planktonic condition, because the cells were washed out (Figure 5B). These data suggest that AtaA-mediated immobilization is tenacious enough to enable continuous hydrogen production in the flow reactor. 


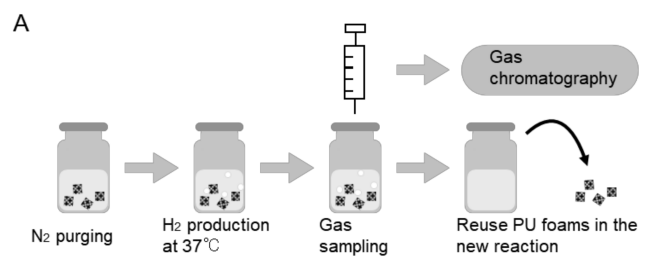

B
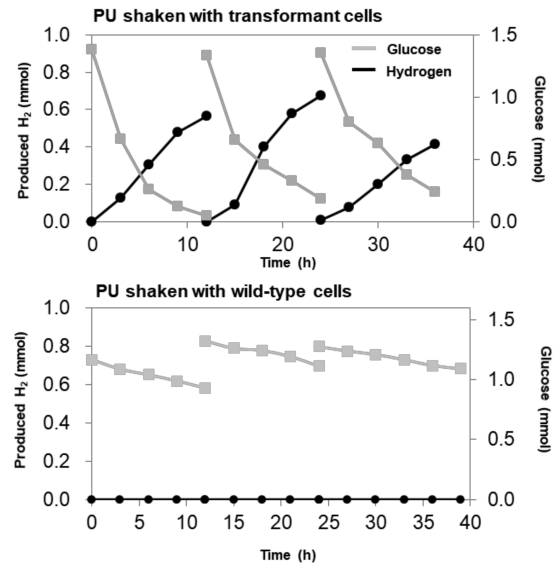

Figure 4. Repetitive hydrogen production by immobilized E. aerogenes in batch reactions. (A) Repetitive batch reactions utilizing polyurethane foams shaken with the transformant or wild-type cells; (B) hydrogen yields (black) and glucose consumptions (gray) measured during the three repetitive batches.
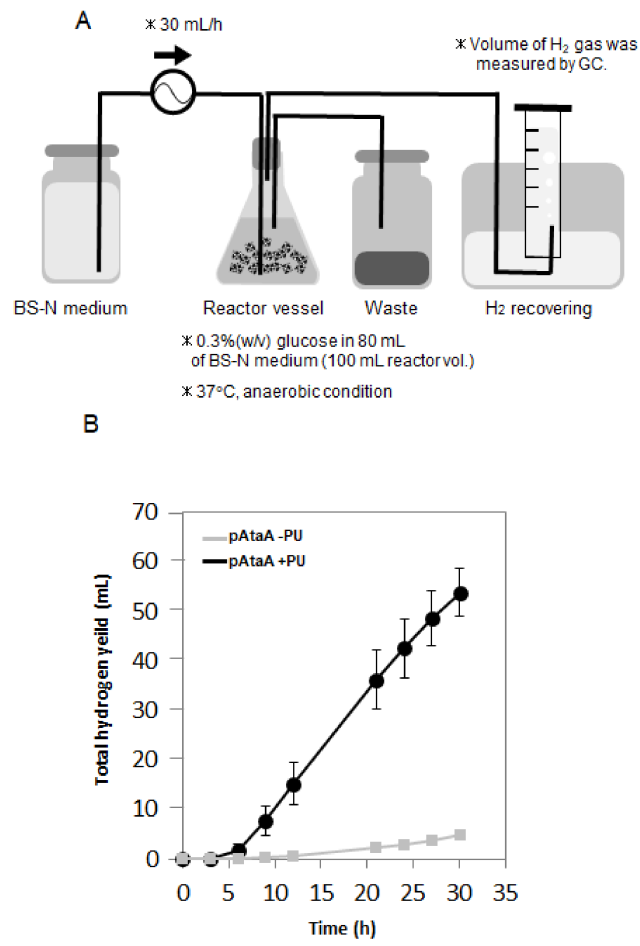

Figure 5. Continuous hydrogen production by immobilized E. aerogenes in a flow reactor. The flow reactor was inoculated with immobilized or planktonic cells. (A) Measurement procedure of hydrogen yields during the reactions. (B) Hydrogen yield versus time in the flow reactor with immobilized-cells on polyurethane (pAtaA +PU: black) and with the planktonic-cell (pAtaA -U: gray). Data are the mean $\pm \mathrm{SD}$ of three independent studies. 


\section{Discussion}

We achieved simple and immediate immobilization of E. aerogenes cells by introducing ataA gene. The immobilized bacterial cells were successfully applied in repetitive and continuous hydrogen production.

In previous studies, we demonstrated the heterologous cell-surface production of AtaA in Acinetobacter baylyi ADP1 and sp. ST550 [28,29], but whether heterologous hosts outside the genus Acinetobacter can produce AtaA was not investigated. In this report, we newly demonstrate that AtaA can be produced on the surface of another genus, Enterobacter. This implies that AtaA-mediated bacterial cell immobilization $[28,29]$ is achievable in broader hosts.

To realize large-scale hydrogen production, continuous/repetitive production processes are recommended [13]. Immobilized whole-cell catalysts enable continuous and efficient bioprocessing by maintaining a sufficient cell density in the reactor. Hydrogen-producing microbes are usually immobilized by the gel or resin embedding method using alginate or polyvinyl alcohol (PVA) $[14,18]$. However, this method requires additional gelling and molding processes after mixing the bacteria and gelling agent. Direct immobilization through bacterial biofilm formation has also been reported in previous Enterobacter studies, but these approaches require a long startup period; biofilm formation on a support ranges from $20 \mathrm{~h}$ to over 14 days $[4,17]$. For hydrogen production, AtaA-mediated immobilization offers several advantages over conventional immobilization methods: (1) wide-variety of carrier availability, (2) rapid and tenacious immobilization, and (3) direct immobilization on the surfaces of materials $[24,28,29]$. Moreover, we recently showed that whole-cell catalysts expressing AtaA can be reversibly immobilized on a carrier, enabling the reuse of bacterial cells and supports [33]. This feature is hardly realized in direct immobilization through biofilm formation. The immobilized-cells by AtaA are hardly detached in buffer solution, while they are easily detached in pure water [33]. In this study, the results shown in Figure 5 suggest that the cells on polyurethane were maintained during the continuous reaction over $30 \mathrm{~h}$ without leaching, because the reaction rate did not reduce. Taken together, these considerations imply that the AtaA-based method can improve the cell immobilization process for whole-cell catalyst production, and would likely reduce the production cost of biohydrogen.

We demonstrated that the transformant cells maintained their hydrogen-production ability after displaying AtaA on their surfaces; moreover, the immobilized cells were sufficiently robust to withstand several repeats of the reaction, as well as continuous reaction (Figures 4 and 5). Our results suggest that AtaA-mediated immobilization of E. aerogenes caused no serious damage to the cell. E. aerogenes produces hydrogen from glucose through several metabolic pathways [9], which can be circulated only if the immobilized cells remain viable. Overexpression of membrane proteins such as AtaA is commonly considered to become toxic, because the excessively produced proteins disrupt the bacterial membrane structures [34-36]. In our previous report, we unexpectedly found that immobilization of bacteria by surface production of AtaA causes no damage to the cells [33]. Moreover, the over expression of ataA did not seem to affect severely on E. aerogenes's growth. In fact, we could prepare the cells producing AtaA at a high cell density $\left(\mathrm{OD}_{600}=4.0\right)$ for immobilization. These features are useful for immobilizing E. aerogenes and other hydrogen-producing Gram-negative bacteria. In the third batch reaction with cell-immobilized polyurethane, however, slight reduction of hydrogen production was observed (Figure 4). Because we restricted a nitrogen source during hydrogen production to prevent cell growth, the resting cells immobilized might gradually have lost their activities during the repetitive reaction.

The hydrogen production in each batch of the triple batch reactions was $0.4-0.6 \mathrm{~mol} / \mathrm{mol}$ glucose, and the hydrogen production rate in the flow reactor was $42 \mathrm{~mL} \cdot \mathrm{h}^{-1} \cdot \mathrm{L}^{-1}$. These values are unremarkable when compared with those of pure Enterobacter spp. cultures in previous laboratory studies [4,17,37-39]. Table 1 summarizes our results with previously reported studies utilizing immobilized Enterobacter for hydrogen production. However, a proper comparison between the present and previous results is difficult, because the experimental conditions such as reactor types, bacterial 
strains used, and operation systems are different among the studies. To further increase the hydrogen yield in our system, it is necessary to increase the immobilized-cell mass by examining carriers, design a sophisticated reactor, and optimize operating conditions for hydrogen production. The selection of bacterial strain and implement metabolic engineering of the cells is also important [40-42]. Combining our new simple method for microbial immobilization with knowledge from previous studies would develop a practical biohydrogen production process with high performance.

Table 1. Comparison of hydrogen production with immobilized Enterobacter spp.

\begin{tabular}{|c|c|c|c|c|c|c|c|}
\hline Biocatalyst & $\begin{array}{c}\text { Immobilization } \\
\text { Method }\end{array}$ & $\begin{array}{l}\text { Reactor } \\
\text { Type }\end{array}$ & $\begin{array}{l}\text { Feed } \\
\text { Stock }\end{array}$ & Production Rate & $\begin{array}{c}\text { Conversion } \\
\text { Rate }\end{array}$ & $\begin{array}{c}\text { Advantage/ } \\
\text { Disadvantage }\end{array}$ & Reference \\
\hline $\begin{array}{l}\text { Enterobacter } \\
\text { aerogenes } \\
\text { IAM1183 }\end{array}$ & $\begin{array}{l}\text { Adhesion of } \\
\text { AtaA protein on } \\
\text { polyurethane } \\
\text { foam }\end{array}$ & $\begin{array}{l}\text { CSTR in } \\
\text { Erlenmeyer } \\
\text { flask }\end{array}$ & Glucose & $\begin{array}{l}42 \mathrm{~mL} \cdot \mathrm{h}^{-1} \cdot \mathrm{L}^{-1} \\
(1.87 \\
\left.\mathrm{mmol} \cdot \mathrm{h}^{-1} \cdot \mathrm{L}^{-1}\right)\end{array}$ & $\begin{array}{c}0.6 \mathrm{~mol} / \mathrm{mol} \\
\text { glucose (Batch) }\end{array}$ & $\begin{array}{l}\text { Immediate and direct } \\
\text { immobilization }(2-3 \mathrm{~h}) / \\
\text { Low production rate }\end{array}$ & This study \\
\hline $\begin{array}{l}\text { Enterobacter } \\
\text { aerogenes } \\
\text { ATCC } 13048\end{array}$ & $\begin{array}{l}\text { Gel entrupment } \\
\text { in alginate gel }\end{array}$ & $\begin{array}{l}\text { Packed-bed } \\
\text { tubular } \\
\text { column } \\
\text { reactor } \\
\end{array}$ & Glucose & $\mathrm{n} / \mathrm{d}$ & $\begin{array}{l}9.44 \mathrm{mmol} / \mathrm{g} \\
\text { glucose } \\
(1.7 \mathrm{~mol} / \mathrm{mol} \\
\text { glucose })\end{array}$ & $\begin{array}{c}\text { High conversion rate/ } \\
\text { Complex } \\
\text { immobilization } \\
\text { processes }\end{array}$ & [37] \\
\hline $\begin{array}{l}\text { Enterobacter } \\
\text { aerogenes } \\
\text { HO-39 }\end{array}$ & $\begin{array}{l}\text { Adsorptionon } \\
\text { porous glass } \\
\text { beads }\end{array}$ & $\begin{array}{l}\text { Packed-bed } \\
\text { column } \\
\text { reactor }\end{array}$ & Glucose & $\begin{array}{c}850 \mathrm{~mL} \cdot \mathrm{h}^{-1} \cdot \mathrm{L}^{-1} \\
\left(37 \mathrm{mmol} \cdot \mathrm{h}^{-1} \cdot \mathrm{L}^{-1}\right)\end{array}$ & $\begin{array}{l}0.73 \mathrm{~mol} / \mathrm{mol} \\
\text { glucose }\end{array}$ & $\begin{array}{c}\text { High production rate/ } \\
\text { complex } \\
\text { immobilization } \\
\text { processes }\end{array}$ & [38] \\
\hline $\begin{array}{l}\text { Enterobacter } \\
\text { cloacae } \\
\text { IIT-BT } 08\end{array}$ & $\begin{array}{c}\text { Biofilm } \\
\text { formation on } \\
\text { Lignocellulosic } \\
\text { agroresidues }\end{array}$ & $\begin{array}{l}\text { Packed-bed } \\
\text { reactor }\end{array}$ & Glucose & $75.6 \mathrm{mmol} \cdot \mathrm{h}^{-1} \cdot \mathrm{L}^{-1}$ & $\mathrm{n} / \mathrm{d}$ & $\begin{array}{l}\text { High production rate/ } \\
\text { Long setup time }(20 \mathrm{~h})\end{array}$ & {$[4]$} \\
\hline $\begin{array}{l}\text { Enterobacter } \\
\text { aerogenes } \\
\text { E.82005 }\end{array}$ & $\begin{array}{l}\text { Biofilm } \\
\text { formation on } \\
\text { polyurethane } \\
\text { foam }\end{array}$ & $\begin{array}{l}\text { Hand-made } \\
\text { fermenter }\end{array}$ & $\begin{array}{l}\text { Molasses } \\
\text { from a } \\
\text { sugar } \\
\text { refinery }\end{array}$ & $\stackrel{13}{\mathrm{mmol}^{-1} \mathrm{~h}^{-1} \cdot \mathrm{L}-\text { culture }^{-1}}$ & $1.5-3.5 \mathrm{~mol} / \mathrm{mol}$ & $\begin{array}{l}\text { High production and } \\
\text { conversion rate/ } \\
\text { Long setup time } \\
\text { (14 days) }\end{array}$ & [17] \\
\hline
\end{tabular}

$\mathrm{n} / \mathrm{d}$ : Not determined.

\section{Materials and Methods}

\subsection{Materials}

Luria-Bertani (LB) medium was purchased from Nakarai Tesque (Kyoto, Japan). Glucose, anmonium sulfate, ampicillin, and gentamicin were purchased from Fujifilm Wako Pure Chemical Corp. (Osaka, Japan). Polyurethane foam (CFH-40) was given from Inoac Corp. (Nagoya, Japan). $\mathrm{N}_{2}$ gas and argon gas were purchased from Sogo Kariya Sanso (Nagoya, Japan).

\subsection{Plasmid Construct, Bacterial Strains, and Culture Conditions}

The plasmid construct, pAtaA [19], was used for ataA gene expression in E. aerogenes.

The bacterial strains used were E. aerogenes IAM1183, its transformant harboring pAtaA, and a $\triangle$ AtaA mutant of Acinetobacter sp. Tol 5 harboring pAtaA (Tol 5 4140::pAtaA) [43]. Cells of all strains were grown aerobically in New Brunswick Scientific (NBS) mineral salts medium or Luria-Bertani (LB) medium at $30{ }^{\circ} \mathrm{C}$ with shaking. To cultivate the transformant cells, the antibiotics ampicillin $(100 \mu \mathrm{g} / \mathrm{mL})$ and gentamicin $(10 \mu \mathrm{g} / \mathrm{mL})$ were added to the growth media. To induce ataA expression on the plasmid construct, $0.5 \%(w / v)$ arabinose was added to the NBS medium. After transferring the seed culture to the induction medium, AtaA production on the cells was promoted by incubation for $12 \mathrm{~h}$ at $30^{\circ} \mathrm{C}$. 


\subsection{Transformation of E. aerogenes and Isolation of the Transformants}

Enterobacter aerogenes was transformed by conjugal transfer as previously described [20], with slight modification of the transformant selection processes. The chemically competent cells of Escherichi coli S17-1 strain [44] were transformed with pAtaA, which was passed by conjugal transfer to E. aerogenes. The transformants obtained by conjugal transfer were selected by the color change of the medium on Shimon's citrate agar plates [45] supplemented with ampicillin and gentamicin.

\subsection{Analysis of AtaA Production by E. aerogenes Transformants}

To confirm AtaA production on the outer membranes of the transformants, the bacterial cells were collected from liquid culture, and the proteins on their outer membranes were extracted, separated by SDS-PAGE, and immunoblotted with anti-AtaA $\mathrm{A}_{699-1014}$ antibody [20]. The production of AtaA on the cells was then confirmed by flow cytometry. The extraction, immunoblotting, and flow cytometry procedures were described previously [20]. The data were obtained by a FACSCanto II flow cytometer (BD biosciences, San Jose, CA, USA), and were further analyzed by comparing their fluorescence intensities using FlowJo software (TOMY digital biology, Tokyo, Japan).

Adherence and tube-settling assays of the transformant were performed as previously described [24], with slight modifications. Bacterial cell suspensions in BS-N medium (prepared at $\left.\mathrm{OD}_{600}=4.0\right)$ were injected into the wells of a 48-well PS plate or test tubes as described previously [24].

\subsection{Cell Immobilization on Polyurethane}

To check the immobilization of resting cells, E. aerogenes and its transformant were prepared as previously described [28]. A bacterial cell suspension (grown to $\mathrm{OD}_{600}=4.0$ ) was transferred to a $100-\mathrm{mL}$ Erlenmeyer flask containing polyurethane foams with a specific surface area of $50 \mathrm{~cm}^{2} / \mathrm{cm}^{3}$ $\left(1 \mathrm{~cm}^{3}\right.$ cubes). The cells were immobilized on the polyurethane foams by incubating the flask at $30^{\circ} \mathrm{C}$ with shaking at $115 \mathrm{rpm}$ for $2 \mathrm{~h}$ in $20 \mathrm{~mL}$ of BS-N medium as previously described [28].

The DCW of the immobilized cell mass was quantified as described previously [28]. The packed cell density was calculated by dividing the immobilized cell mass (i.e., the DCW) by the immobilzation support volume, which was calculated as described previously [28].

\subsection{Hydrogen Production by the Immobilized Cells}

Repetitive hydrogen production in the batch reactor was started by adding 20 pieces of the polyurethane foams holding the immobilized cells to $30 \mathrm{~mL}$ of BS-N medium supplemented with $0.5 \%$ glucose and $0.02 \mathrm{~g} / \mathrm{L}\left(\mathrm{NH}_{4}\right)_{2} \mathrm{SO}_{4}$ in a sealed vial. The head-space gas was switched to $\mathrm{N}_{2}$, and the vial was incubated at $37^{\circ} \mathrm{C}$. During the incubation, the gases produced were collected by a gass-tight syringe, and their hydrogen content was measured by gas chromatography at designated time intervals $(0,3,6,8,12,15,18,21,27,30,33$, and $36 \mathrm{~h})$. The glucose concentration in the reaction medium was measured by a Glucose CII-Test Wako kit (Wako, Osaka, Japan) following the manufacturer's instructions. At the end of every batch reaction (i.e., after 12 and $24 \mathrm{~h}$ operation), carrier pieces were collected from the vial, washed in $300 \mathrm{~mL}$ BS-N medium for $5 \mathrm{~min}$, dewatered on a paper towel for $2 \mathrm{~min}$, and transferred to the new reaction medium in the new vial for the next reaction.

Hydrogen production by the ataA-expressing cells in the flow reactor was started by loading the immobilized cells (50 pieces of polyurethane foam) or planktonic cells into a $100 \mathrm{~mL}$ Erlenmeyer flask containing $80 \mathrm{~mL}$ of BS-N medium was supplemented with $0.3 \%(w / v)$ glucose and $0.02 \mathrm{~g} / \mathrm{L}$ $\left(\mathrm{NH}_{4}\right)_{2} \mathrm{SO}_{4}$. The air in the head space of the flask was purged by filling with $\mathrm{N}_{2}$ gas. Fresh medium was supplied through an inlet line in the flask at a flow rate of $30 \mathrm{~mL} / \mathrm{h}$. At the same time, the spent medium in the flask was expelled through an outlet line at the same flow rate. The gas produced was collected by the downward displacement of water through the sampling line. 


\subsection{Quantification of $\mathrm{H}_{2}$ Production by Gas Chromatography Coupled to a Thermal Conductivity Detector $(G C-T C D)$}

The produced $\mathrm{H}_{2}$ was quantified by gas chromatography (CG) (GC-2014; Shimadzu, Kyoto, Japan) equipped with a thermal conductivity detector (TCD) and a SHINCARBON-ST packed column $\left(4.0 \mathrm{~m} \times 3.0 \mathrm{~mm} \phi\right.$, Shinwakako; Kyoto, Japan). The TCD was set to $150{ }^{\circ} \mathrm{C}$. The recovered gas was injected into the GC-TCD. The carrier gas was argon flowing at $25 \mathrm{~mL} / \mathrm{min}$. The GC operating program was run in isocratic mode at $40{ }^{\circ} \mathrm{C}$ for $12 \mathrm{~min}$. The $\mathrm{H}_{2}$ peak was detected at a retention time of $3.3 \mathrm{~min}$. The $\mathrm{H}_{2}$ production was calculated from the peak area.

Acknowledgments: This work was supported by a Strategic International Research Cooperative Program from JST. We thank Leonie Pipe, PhD, from Edanz Group (www.edanzediting.com/ac) for editing a draft of this manuscript.

Author Contributions: K.H., H.N., and Y.O. designed the study, and H.N. and K.H. wrote the paper. N.D. obtained the transformant cells, analyzed the cells by flow cytometry, and measured the hydrogen production. Y.O. conducted the SDS-PAGE and immunoblotting. N.D., H.N., and Y.O. analyzed the data. All authors reviewed the manuscript.

Conflicts of Interest: The authors declare that they have no conflicts of interest with the contents of this article.

\section{References}

1. Mudhoo, A.; Forster-Carneiro, T.; Sánchez, A. Biohydrogen production and bioprocess enhancement: A review. Crit. Rev. Biotechnol. 2011, 31, 250-263. [CrossRef] [PubMed]

2. Kalinci, Y.; Hepbasli, A.; Dincer, I. Biomass-based hydrogen production: A review and analysis. Int. J. Hydrog. Energy 2009, 34, 8799-8817. [CrossRef]

3. Fang, H.H.P.; Liu, H.; Zhang, T. Bio-hydrogen production from wastewater. Water Sci. Technol. Water Supply 2004, 4, 77-85.

4. Kumar, N.; Das, D. Continuous hydrogen production by immobilized Enterobacter cloacae IIT-BT 08 using lignocellulosic materials as solid matrices. Enzyme Microb. Technol. 2001, 29, 280-287. [CrossRef]

5. Tanisho, S.; Ishiwata, Y. Continuous hydrogen production from molasses by the bacterium Enterobacter aerogenes. Int. J. Hydrog. Energy 1994, 19, 807-812. [CrossRef]

6. Xu, Y.; Jiang, Y.; Chen, Y.; Zhu, S.; Shen, S. Hydrogen production and wastewater treatment in a microbial electrolysis cell with a biocathode. Water Environ. Res. 2014, 86, 649-653. [CrossRef] [PubMed]

7. Miyake, J. Hydrogen Production Using Photosynthetic Bacteria. In Microbial Production; Anazawa, H., Shimizu, S., Eds.; Springer: Tokyo, Japan, 2014; pp. 263-281, ISBN 978-4-431-54606-1.

8. Logan, B.E.; Call, D.; Cheng, S.; Hamelers, H.V.; Sleutels, T.H.; Jeremiasse, A.W.; Rozendal, R.A. Microbial electrolysis cells for high yield hydrogen gas production from organic matter. Environ. Sci. Technol. 2008, 42, 8630-8640. [CrossRef] [PubMed]

9. Lee, D.-J.; Show, K.-Y.; Su, A. Dark fermentation on biohydrogen production: Pure culture. Bioresour. Technol. 2011, 102, 8393-8402. [CrossRef] [PubMed]

10. Tanisho, S.; Wakao, N.; Kosako, Y. Biological hydrogen production by Enterobacter aerogenes. J. Chem. Eng. Jpn. 1983, 16, 529-530. [CrossRef]

11. Ito, T.; Nakashimada, Y.; Kakizono, T.; Nishio, N. High-yield production of hydrogen by Enterobacter aerogenes mutants with decreased a-acetolactate synthase activity. J. Biosci. Bioeng. 2004, 97, 227-232. [CrossRef]

12. Ren, Y.; Wang, J.; Liu, Z.; Ren, Y.; Li, G. Hydrogen production from the monomeric sugars hydrolyzed from hemicellulose by Enterobacter aerogenes. Renew. Energy 2009, 34, 2774-2779. [CrossRef]

13. Argun, H.; Kargi, F. Bio-hydrogen production by different operational modes of dark and photo-fermentation: An overview. Int. J. Hydrog. Energy 2011, 36, 7443-7459. [CrossRef]

14. Bagai, R.; Madamwar, D. Prolonged evolution of photohydrogen by intermittent supply of nitrogen using a combined system of Phormidium valderianum, Halobacterium halobium, and Escherichia coli. Int. J. Hydrog. Energy 1998, 23, 545-550. [CrossRef]

15. Chang, J.-S.; Lee, K.-S.; Lin, P.-J. Biohydrogen production with fixed-bed bioreactors. Int. J. Hydrog. Energy 2002, 27, 1167-1174. [CrossRef] 
16. Liu, Z.D.; Lv, F.X.; Zheng, H.; Zhang, C.; Wei, F.; Xing, X.H. Enhanced hydrogen production in a UASB reactor by retaining microbial consortium onto carbon nanotubes (CNTs). Int. J. Hydrog. Energy 2012, 37, 10619-10626. [CrossRef]

17. Tanisho, S.; Ishiwata, Y. Continuous hydrogen production from molasses by fermentation using urethane foam as a support of flocks. Int. J. Hydrog. Energy 1995, 20, 541-545. [CrossRef]

18. Wu, S.-Y.; Lin, C.-N.; Chang, J.-S.; Lee, K.-S.; Lin, P.-J. Microbial hydrogen production with immobilized sewage sludge. Biotechnol. Prog. 2002, 18, 921-926. [CrossRef] [PubMed]

19. Yokoi, H.; Maeda, Y.; Hirose, J.; Hayashi, S.; Takasaki, Y. $\mathrm{H}_{2}$ production by immobilized cells of Clostridium butyricum on porous glass beads. Biotechnol. Tech. 1997, 11, 431-433. [CrossRef]

20. Ishikawa, M.; Nakatani, H.; Hori, K. AtaA, a new member of the trimeric autotransporter adhesins from Acinetobacter sp. Tol 5 mediating high adhesiveness to various abiotic surfaces. PLoS ONE 2012, 7, e48830. [CrossRef] [PubMed]

21. Hori, K.; Yamashita, S.; Ishii, S.; Kitagawa, M.; Tanji, Y.; Unno, H. Isolation, characterization and application to off-gas treatment of toluene-degrading bacteria. J. Chem. Eng. Jpn. 2001, 34, 1120-1126. [CrossRef]

22. Hori, K.; Ishikawa, M.; Yamada, M.; Higuchi, A.; Ishikawa, Y.; Ebi, H. Production of peritrichate bacterionanofibers and their proteinaceous components by Acinetobacter sp. Tol 5 cells affected by growth substrates. J. Biosci. Bioeng. 2011, 111, 31-36. [CrossRef] [PubMed]

23. Ishii, S.; Unno, H.; Miyata, S.; Hori, K. Effect of cell appendages on the adhesion properties of a highly adhesive bacterium, Acinetobacter sp. Tol 5. Biosci. Biotechnol. Biochem. 2006, 70, 2635-2640. [CrossRef] [PubMed]

24. Ishikawa, M.; Shigemori, K.; Suzuki, A.; Hori, K. Evaluation of adhesiveness of Acinetobacter sp. Tol 5 to abiotic surfaces. J. Biosci. Bioeng. 2012, 113, 719-725. [CrossRef] [PubMed]

25. Ishii, S.; Koki, J.; Unno, H.; Hori, K. Two morphological types of cell appendages on a strongly adhesive bacterium, Acinetobacter sp. Strain Tol 5. Appl. Environ. Microbiol. 2004, 70, 5026-5029. [CrossRef] [PubMed]

26. Hoiczyk, E.; Roggenkamp, A.; Reichenbecher, M.; Lupas, A.; Heesemann, J. Structure and sequence analysis of Yersinia YadA and Moraxella UspAs reveal a novel class of adhesins. EMBO J. 2000, 19, 5989-5999. [CrossRef] [PubMed]

27. Linke, D.; Riess, T.; Autenrieth, I.B.; Lupas, A.; Kempf, V.A.J. Trimeric autotransporter adhesins: Variable structure, common function. Trends Microbiol. 2006, 14, 264-270. [CrossRef] [PubMed]

28. Hori, K.; Ohara, Y.; Ishikawa, M.; Nakatani, H. Effectiveness of direct immobilization of bacterial cells onto material surfaces using the bacterionanofiber protein AtaA. Appl. Microbiol. Biotechnol. 2015, 99, 5025-5032. [CrossRef] [PubMed]

29. Ishikawa, M.; Shigemori, K.; Hori, K. Application of the adhesive bacterionanofiber AtaA to a novel microbial immobilization method for the production of indigo as a model chemical. Biotechnol. Bioeng. 2014, 111, 16-24. [CrossRef] [PubMed]

30. Xing, X.H.; Jun, B.H.; Yanagida, M.; Tanji, Y.; Unno, H. Effect of C/N values on microbial simultaneous removal of carbonaceous and nitrogenous substances in wastewater by single continuous-flow fluidized-bed bioreactor containing porous carrier particles. Biochem. Eng. J. 2000, 5, 29-37. [CrossRef]

31. Guo, W.; Ngo, H.-H.; Dharmawan, F.; Palmer, C.G. Roles of polyurethane foam in aerobic moving and fixed bed bioreactors. Bioresour. Technol. 2010, 101, 1435-1439. [CrossRef] [PubMed]

32. Feng, Q.; Wang, Y.; Wang, T.; Zheng, H.; Chu, L.; Zhang, C.; Chen, H.; Kong, X.; Xing, X.-H. Effects of packing rates of cubic-shaped polyurethane foam carriers on the microbial community and the removal of organics and nitrogen in moving bed biofilm reactors. Bioresour. Technol. 2012, 117, 201-207. [CrossRef] [PubMed]

33. Yoshimoto, S.; Ohara, Y.; Nakatani, H.; Hori, K. Reversible bacterial immobilization based on the salt-dependent adhesion of the bacterionanofiber protein AtaA. Microb. Cell Fact. 2017, 16. [CrossRef] [PubMed]

34. Thai, K.; Choi, J.; Franzin, C.M.; Marassi, F.M. Bcl-xl as a fusion protein for the high-level expression of membrane-associated proteins. Protein Sci. 2005, 14, 948-955. [CrossRef] [PubMed]

35. Diefenderfer, C.; Lee, J.; Mlyanarski, S.; Guo, Y.; Glover, K.J. Reliable expression and purification of highly insoluble transmembrane domains. Anal. Biochem. 2009, 384, 274-278. [CrossRef] [PubMed]

36. Laage, R.; Langosch, D. Strategies for prokaryotic expression of eukaryotic membrane proteins. Traffic 2001, 2, 99-104. [CrossRef] [PubMed] 
37. Satar, I.; Ghasemi, M.; Aljlil, S.A.; Isahak, W.N.R.W.; Abdalla, A.M.; Alam, J.; Daud, W.R.W.; Yarmo, M.A.; Akbarzadeh, O. Production of hydrogen by Enterobacter aerogenes in an immobilized cell reactor. Int. J. Hydrog. Energy 2017, 42, 9024-9030. [CrossRef]

38. Yokoi, H.; Tokushige, T.; Hirose, J.; Hayashi, S.; Takasaki, Y. Hydrogen production by immobilized cells of aciduric Enterobacter aerogenes strain HO-39. J. Ferment. Bioeng. 1997, 83, 481-484. [CrossRef]

39. Palazzi, E.; Fabiano, B.; Perego, P. Process development of continuous hydrogen production by Enterobacter aerogenes in a packed column reactor. Bioprocess Eng. 2000, 22, 205-213. [CrossRef]

40. Lu, Y.; Lai, Q.; Zhang, C.; Zhao, H.; Xing, X.-H. Alteration of energy metabolism in Enterobacter aerogenes by external addition of pyrophosphates and overexpression of polyphosphate kinase for enhanced hydrogen production. J. Chem. Technol. Biotechnol. 2012, 87, 996-1003. [CrossRef]

41. Zhang, C.; Lv, F.-X.; Xing, X.-H. Bioengineering of the Enterobacter aerogenes strain for biohydrogen production. Bioresour. Technol. 2011, 102, 8344-8349. [CrossRef] [PubMed]

42. Goyal, Y.; Kumar, M.; Gayen, K. Metabolic engineering for enhanced hydrogen production: A review. Can. J. Microbiol. 2012, 59, 59-78. [CrossRef] [PubMed]

43. Ishikawa, M.; Hori, K. A new simple method for introducing an unmarked mutation into a large gene of non-competent gram-negative bacteria by FLP/FRT recombination. BMC Microbiol. 2013, 13, 86. [CrossRef] [PubMed]

44. Simon, R.; Priefer, U.; Pühler, A. A broad host range mobilization system for in vivo genetic engineering: Transposon mutagenesis in gram negative bacteria. Nat. Biotechnol. 1983, 1, 784-791. [CrossRef]

45. Simmons, J.S. A culture medium for differentiating organisms of typhoid-colon aerogenes groups and for isolation of certain fungi. J. Infect. Dis. 1926, 39, 209-214. [CrossRef]

(C) 2018 by the authors. Licensee MDPI, Basel, Switzerland. This article is an open access article distributed under the terms and conditions of the Creative Commons Attribution (CC BY) license (http:/ / creativecommons.org/licenses/by/4.0/). 